\title{
PENGEMBANGAN UMKM BERBASIS INOVASI PRODUK DAN E-COMMERCE DI DESA WANGON BANYUMAS
}

\author{
Endra Saputra \\ Universitas Muhammadiyah Purwokerto \\ endrasaputra2912@gmail \\ Nur Isna Inayati \\ Universitas Muhammadiyah Purwokerto \\ nurisnainayati@ump.ac.id \\ Annisa IIma Hartikasari \\ Universitas Muhammadiyah Purwokerto \\ email
}

\section{Article History:}

Received: 31 Mei 2021

Revised: -

Accepted: 5 Juni 2021

DOI:

10.29303/abdimassangkabi ra.v1i2.35

\begin{abstract}
Abstrak: salah satu bentuk inovasi yang mendongkrak suatu perokonomian daerah setempat bahkan negara. Pemberdayaan masyarakat social melalui pendekatan pengembangan UMKM melalui kelompok masyarakat akan berdampak positif terhadap perkembangan desa terutama desa Wangon Kabupaten Banyumas. Hal yang mendasari pengabdian ini adalah adanya komoditas unggulan yang berada di desa wangon yakni berupa gula merah yang bisa dijadikan suatu produk baru yang dapat menambah penghasilan daerah setempat. Permasalahan yang dihadapi oleh masyarakat yakni belum adanya tekhnologi yang modern yang mempercepat proses produksi serta pembukuan dan pemasaran yang bisa menambah proses produksi dan kelancaran produksi
\end{abstract}

Kata kunci : produk, e-commerce, UMKM

\section{Pendahuluan}

Wangon adalah kecamatan yang berada di Kabupaten Banyumas, Provinsi Jawa Tengah, Indonesia. Kecamatan Wangon dikenal akan penghasil gula merah terbesar di banyumas dengan luas perkebunan kelapa mencapai $1.223,30 \mathrm{Ha}$.

Nira kelapa adalah cairan bening yang keluar dari bunga kelapa dan aren yang pucuknya belum membuka, cairan ini merupakan bahan baku untuk pembuatan gula jawa atau gula merah. Nira sering juga dibuat "legen" kata ini sebenarnya istilah bahasa jawa berasal dari kata legi artinya manis. Dalam keadaan segar nira mempunyai rasa manis berbau 


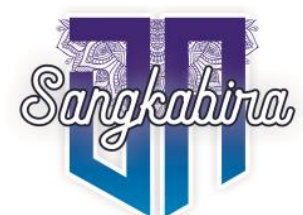

Vol. 1, No. 2, Juni 2021

harum dan tidak berwarna. Selain bahan baku pembuatan gula nira dapat pula digunakan sebagai bahan makanan lain yaitu minuman keras (tuak), asam cuka dan minuman segar (Muchtadi dan Sugiyono, 1992).

Menurut penelitian Trisnamurti (1999), nira kelapa yang berkualitas baik dan masih segar mempunyai rasa manis, berbau harum, tidak berwarna, derajat keasaman $(\mathrm{pH})$ berkisar 6-7, dan kandungan gula reduksinya relatif rendah. Perlu diketahui nira kelapa yang merupakan bahan utama gula jawa ini mudah mengalami fermentasi karena kandungan nutrisinya merupakan substrat yang baik bagi pertumbuhan mikroba ditandai dengan bau menyengat, warna nira menguning dan rasa masam. Naufalin (2012), Nira kelapa merupakan bahan baku dalam pembuatan gula kelapa. Gula kelapa cetak mudah mengalami kerusakan, baik pada saat penanganan bahan baku, proses pengolahan maupun pasca pengolahan. Penanganan bahan baku yang kurang tepat akan mempersulit proses pengolahan dan dapat menyebabkan kegagalan. Oleh karena itu perlu adanya proses pengawetan selama proses penyimpanan nira, yaitu selama proses penyadapan hingga saat akan diolah menjadi gula kelapa. Pengawetan yang biasa dilakukan oleh petani adalah pemberian laru pada wadah penampung nira atau pongkor. Laru tersebut terbuat dari $\mathrm{Ca}(\mathrm{OH}) 2$ yang dikombinasikan dengan kulit buah manggis atau tatal kayu nangka. Pembuatan larutan $\mathrm{Ca}(\mathrm{OH}) 2$ tidak memiliki standar konsentrasi pemberian yang tetap, hanya berdasarkan daya perkiraan petani, sehingga hal itu menjadi salah satu penyebab ketidakstabilan kualitas nira. Dengan demikian sangat penting adanya perlakuan tentang konsentrasi pemberian $\mathrm{Ca}(\mathrm{OH}) 2$ untuk mendapatkan kualitas nira yang baik dan stabil.

Di Kabupaten Banyumas usaha peternakan sapi perah berawal dari penyebaran bibit sapi perah jenis Fresian Holstein (FH), oleh Proyek Pengembangan Sapi Perah bantuan MEE, melalui sumbu kontrak di Kabupaten Banyumas pada tahun 1987. Untuk melindungi dan mengembangkan usahanya, Proyek Pengembangan Sapi Perah Bantuan MEE membentuk Koperasi Primer, dengan nama Koperasi Sapi Perah Rakyat Banyumas "SUPRABA" yang di sahkan pada tanggal 31 Oktober 1987 dngan nomor 1096/BH/VI. Koperasi tersebut semakin berkembang dari tahun ke tahun sehingga muncul untuk membuka usaha baru yaitu usaha pembesaran pedet betina. Setelah melalui pembahasan di tingkat pusat, maka Dirjen Peternakan dan Dirjen Binuskop pusat Jakarta, menugaskan kepada Koperasi "SUPRABA" untuk meningkatkan kualitas pedet keturunan sapi perah eks import untuk mengurangi import sapi perah dari luar negeri.

Berdasarkan data di atas penulis bermaksud untuk membuat sebuah produk unggulan yang berbahan utama dari nira kelapa dan susu perah, pembukuan serta pemasaran yang nantinya dapat mengembangkan UMKM desa Wangon. Susu adalah sumber kalsium 
terbaik yang berguna untuk menguatkan tulang. Teratur minum susu dapat menjaga tulang agar tetap sehat dan kuat. Terkadang Vitamin D juga ditambahkan ke dalam produk susu. Vitamin D ini dipercaya membantu meningkatkan pertumbuhan tulang, sehingga risiko terkena osteoporosis dapat dikurangi (halodoc artikel). Komposisi nira terdiri dari air, sukrosa, gula reduksi, bahan organik lain, dan bahan anorganik. Air dalam nira merupakan bagian yang terbesar yaitu antara $75-90 \%$. Sukrosa merupakan bagian zat padat yang terbesar berkisar antara 12,30 - 17,40 \%. Gula reduksi antara 0,50 - 1,00 \% dan sisanya merupakan senyawa organik serta anorganik. Dengan masing masing keunggulan gizi akan sangat baik untuk membuat produk dengan berbahan dasar dari susu sapi perah dan nira kelapa (Susu Nira Murni).

\section{Metode}

Dengan adaya melimpahnya kedua bahan tersebut untuk diolah menjadi sebuah produk. Serta dengan adanya pandemi di Indonesia yang membuat penjualan di kedua bahan tersebut turun dari penjualan ratarata sebelum pandemi. Hal tersebut menyebabkan tidak adanya permintaan dari dunia industry seperti pabrik kecap dan pabrik susu kemasan. Petani dan peternak merasa kecewa karena kehilangan pelanggan utamanya dalam menjual hasil olahan. Dalam hal ini penulis membuat suatu wadah perkumpulan yang dimana bekerjasama dengan UMKM dan pemerintah desa Wangon untuk bekerjasama menjadikan produk unggulan desa wangon menjadi produk inovasi yang baru dan berkualitas yang mampu bersaing dan bertahan di tengah pandemi. Dalam hal ini penulis memberikan pengarahan kepada masyarakat desa setempat terkait dengan pembuatan produk, pembukuan serta pemasaran produk yang dimana bermaksud agar masyarakat desa wangon menjadi masyarakat melek dengan IT sehingga dapat memaksimalkan hasil produksi susu nira murni menjadi produk unggulan. Metode pelaksanaan yakni dengan cara pendekatan secara langsung memberikan pelatihan kepada masyarakat dan UMKM baik berupa pengolahan produk, pembukuan dan pemasaran melalui market place. 
Vol. 1, No. 2, Juni 2021

Mengubah Mindset Masyarakat Agar Pola Pikir Masyarakat Yang Tadinya

sederhana Menjadi Modern.

Pendampingan Implementasi Kegiatan Pengolahan Produk,Pelatihan

Pembukuan dan Pelatihan Pemasaran Melalui E-commerce Maupun Media

Cetak.

Pendampingan dan Pembinaan dengan Membentuk UMKM Untuk Menjadi Sumber

Pendapatan di Desa Tersebut.

Gambar 1. Diagram Round Map

\section{Hasil}

Hasil yang dihasilkan dengan diadakanya program ini adalah terbentuknya UMKM yang berkualitas dengan adanya pelatihan yang sudah diberikan seperti pengolahan produk,pembukuan serta pemasaran yang telah dilakukan. Pengolahan produk memberikan inovasi baru bagi masyarakat desa wangon, pembukuan melatih masyarakat desa wangon menjadi ahli bagaimana mengelola keuangan dalam proses produksi dan pemasaran produk membuat warga masyarakat wangon menjadi tahu bagaimana bermain market place yang dapat menghasilkan pendapatan. Selain itu terciptanya perilaku masyarakat sosial yang hanya mengunakan proses produksi menggunakan alat-alat tradisional sekarang bisa menggunakan alat-alat modern serta Menjalin Kemitraan dengan menggandeng berbagai stakeholder seperti dropshit ke beberapa lokasi cafe/kedai, e-commerce, bahkan ekspor.

\section{Diskusi}

Berdasarkan hasil penelitian penulis bahwasanya suatu perekonomian akan berkembang maju apabila segala aspek ada didalamnya seperti pengolahan produk, pembukuan, pemasaran,pengiriman (Darwanto.(2013).Pengembangan UMKM berbasis inovasi produk dan ecommerce di desa wangon merupakan suatu tindakan yang baik dikarenakan desa wangon mempunyai komoditas yang unggul yakni gula merah serta masyarakat masih menjaga kaslian produk tersebut. Dengan adanya pelatihan seperti ini akan berdampak positif bagi masyarakat setempat dan pelaku UMKM yang berada di desa wangon. Kebiasaan lama yang masih menggunakan alat-alat tradisional sekarang sudah menjadi alat-alat modern yang meringankan pekerjaan berat. 


\section{Kesimpulan}

Pengabdian ini bertujuan untuk meningkatkan UMKM yang berada diwilayah Banyumas terutama desa wangon. Pengembangan UMKM menggunakan metode pengolahan produk, pembukuan serta pemasaran suatu produk akan mempengaruhi atau menambah suatu nilai psositif yang tadinya hanya menggunakan alat tradisional sekarang dilatih untuk menggunakan alat-alat modern (Departemen Perdagangan Republik Indonesia, 2008).

\section{Pengakuan/Acknowledgements}

Peneliti mengucapkan terimakasih kepada warga masyarakat desa wangon, Pelaku UMKM dan Kepala Desa Wangon atas informasi yang telah diberikan langsung. Selain itu, peneliti mengucapkan terimakasih kepada NUR ISNA INAYATI S.ST. M.Si. dan ANNISA ILMA HARTIKASARI, S.E., M.Sc., Ak. selaku pembimbing dan memberikan masukan yang telah diberikan.

\section{Daftar Referensi}

Anggraeni, F. D. (2013). "Pengembangan Usaha Mikro, Kecil, dan Menengah (UMKM) Melalui Fasilitas Pihak Eksternal dan Potensi Internal (Studi Kasus pada KelompokUsaha "Emping Jagung" di Kelurahan Pandanwangi Kecamatan Blimbing, Kota Malang). Jurnal Administrasi Publik, Vol. 1, No. 6, hlm: 1286-1295.

Departemen Perdagangan Republik Indonesia. (2008). Cetak Biru Pengembangan Ekonomi Kreatif Indonesia 2025. Jakarta: Studi Industri Kreatif Indonesia, Departemen Perdagangan.

Muchtadi, T. R. \& Sugiyono. (1992). Ilmu Pengetahuan Bahan Pangan. Bogor: Institut Pertanian Bogor

Naufalin (2012) Rifda Naufalin , Tri Yanto dan Abdulloh Goro Binardjo. 2012. Penambahan Konsentrasi $\mathrm{Ca}(\mathrm{OH}) 2$ dan Bahan Pengawet Alami untuk Peningkatan Kualitas Nira Kelapa

Satria, D. \& A. Prameswari. (2011). "Strategi Pengembangan Industri Kreatif untuk Meningkatkan Daya Saing Pelaku Ekonomi Lokal". Jurnal Aplikasi Manajemen. Vol.9, No. 1, hlm: 301-308.

Sumarsono, S. (2009). Ekonomi Sumber Daya Manusia Teori dan Kebijakan Publik. Jogyakarta : Graha Ilmu. 
Vol. 1, No. 2, Juni 2021

Trisnamukti, Roy H., Sutrisno, Ela T., Fatimah, Dewi. 1999. Perubahan Kenaikan Titik Didih dan Panas Jenis Larutan pada Pembuatan Gula Semut Aren (Arenga pinnata), Buletin IPT, 5: 36- 40.

https://koperasipesatbms.wordpress.com/

https://www.halodoc.com/artikel/6-makanan-untuk-memperkuat-tulangdan-mencegah-osteoporosis

https://www.bps.go.id/indikator/indikator/view data pub/3302/api pub/O HpDenRSSHlaM29XRmROaUtQUHdoQT09/da 05/2 